be taken without the particular diagnosis being disclosed; all those who need to know can be informed of the high infection risk.

General practitioners and other doctors, alert to the high infection risk state of the patients, are in a better position to question them more closely when illness occurs, with less likelihood of misunderstandings occurring or of dangerous delays in treatment. The control of infection officer (MB) holds a secure list of the diagnoses known to him from the laboratory tests; he can give informed advice when there are serious difficulties with patients with a high infection risk, such as needlestick accidents. We have found this system workable and useful and would recommend it to others.

Departments of Microbiology and

Michael BaRnham Haematology,

Harrogate General Hospital,

Harrogate General Hospital,
North Yorkshire HG2 7ND

MichaEL MCEVOY

\section{Severe rombergism due to gentamicin toxicity}

SIR,-Drs Roderick Duncan and Ian D Melville (31 October, $p$ 1141) describe a case of rombergism with gentamicin toxicity. The patient was a 71 year old man who received gentamicin $80 \mathrm{mg}$ three times a day intramuscularly for eight days and a second similar course lasting six days. The serum gentamicin concentration of $13.6 \mathrm{mg} / 1$ during the second course was presumably a trough value. No values for weight or serum creatinine were given. In this case gentamicin toxicity was probably entirely predictable and therefore preventable.

The British National Formulary recommends that the dose interval for gentamicin should be increased to 12 hours when the creatinine clearance is $30-70 \mathrm{ml} / \mathrm{min}$. Creatinine clearance falls with age, and a number of equations have been developed to predict this from age, sex, weight, and serum creatinine, assuming steady state fluid balance. ${ }^{12}$ All of these variables are available to the clinician before gentamicin is prescribed.

According to the equation derived by Hull and others, ${ }^{1}$ an apparently normal serum creatinine of $90 \mu \mathrm{mol} / \mathrm{l}$ would give a creatinine clearance of greater than $70 \mathrm{ml} / \mathrm{min}$ only if the patient weighed more than $71 \mathrm{~kg}$. Even at the upper end of the normal reference range a serum creatinine of $120 \mu \mathrm{mol} / \mathrm{l}$ would given a creatinine clearance of greater than $70 \mathrm{ml} / \mathrm{min}$ only if the patient weighed over $95 \cdot 7 \mathrm{~kg}$. The patient was probably prescribed a three times daily regimen on the basis that his renal function was normal because the serum creatinine value was within the normal reference range. This is a false premise, and in the elderly there can be important renal impairment with a normal serum creatinine concentration.

There is no place for the automatic prescription of gentamicin three times daily in the elderly. An estimate of creatinine clearance should be made using one of the equations available and the dose interval adjusted accordingly.

Zaske and others have shown that the elderly have wide variations in volume of distribution and elimination rates for gentamicin. ${ }^{3}$ It is important, therefore, to measure serum gentamicin values at least two or three times a week as the concentrations cannot be accurately predicted in spite of initial adjustments in dose and dosage interval.

Had the above factors been taken into account the patient would probably have been spared the symptoms of vestibular toxicity.

David G.SwaIN

Department of Geriatric Medicine,

Sandwell District General Hospital,

West Bromwich B71 4HJ
1 Hull JH, Hak LJ, Koch GG, Wagin WA, Chi SL, Mattocks AM. Influence of range of renal functions and liver disease on predictability of creatinine clearance. Clin Pharm Ther 1981; 29:516-21.

2 Cockroft DW, Gault MH. Prediction of creatinine clearance from serum creatinine. Nephron 1976;16:31-41.

3 Zaske DE, Irvine P, Strand LM, Strate RG, Cipolle RJ, Rotschafer J. Wide interpatient variations in gentamicin dose requirements for geriatric patients. JAMA 1982;248:3122-6.

AUTHORS' REPLY,-We appreciate Dr Swain's helpful reminder that gentamicin toxicity can in general be predicted and avoided. Our own interes in this case was in its neurological features; it seemed to us worth while to point out that severe gentamicin toxicity can be present with no cochlear symptoms and little in the way of obvious vestibular symptoms. We agree entirely that this underlines the need for identifying risk factors and monitoring serum concentrations at appropriate intervals.

We know from the patient's case record at the hospital where he was initially treated that he was seriously ill from a life threatening infection and that this and bacterial sensitivities governed the use of gentamicin. We hope that our case report and Dr Swain's comments increase doctors' awareness of the hazards of gentamicin treatment, especially when its use is required in the elderly patient.

RODERICK DUNCAN IAN D MELVILLE

Institute of Neurological Sciences,

Southern General Hospital,

Glasgow G51 4TF

Gonadotrophin hormone releasing analogues open new doors in cancer treatment

SIR,-Dr Jonathan Waxman (31 October, p 1084) states that depot preparations of gonadotrophin hormone releasing analogues may be an acceptable alternative to orchidectomy in the treatment of prostatic cancer.

Since 1982, 135 patients at Broadgreen Hospital, Liverpool, have undergone subcapsular orchidectomy as part of their treatment for prostatic cancer. ${ }^{1}$ In 100 this was done under local anaesthesia, general anaesthesia being required only for combined procedures. The average age was 72 years (range 48 to 98 years). Three patients refused orchidectomy. We have estimated the cost of treating these 135 patients with the luteinising hormone releasing hormone analogue goserelin if it had been available in 1982 assuming survival to be the same. The total cost would have been $£ 293000$ and the cost in the last financial year $\$ 93000$. When hormone manipulation is indicated there is a cogent argument for the continued use of subcapsular orchidectomy. The costs of the operation are relatively low in National Health Service practice since the procedure requires neither general anaesthesia nor major theatre time and the recovery period is short. Patient acceptability in elderly men is high and the use of the term "mutilating" in this context can only be considered emotive.

Unless luteinising hormone releasing hormone analogues are subsequently shown by controlled clinical trials to offer significant therapeutic benefit over orchidectomy then we suggest that their role in prostatic cancer should be limited to the $2-3 \%$ of patients who refuse orchidectomy.

A J ARNOLD

Broadgreen Hospital,

A D DESMOND

Broadgreen Hospita

1 Desmond AD, Arnold AJ, Hastie KJ, Subcapsular orchidectomy under local anaesthesia. $\mathrm{Br} \mathcal{J}$ Urol (in press).

\section{Waiting for Godot}

SIR,-The Secretary of State for Social Services would like to see every general practitioner with a computer screen on his desk, "so he will be able to tell a patient instantly where in the country there is a hospital place available for his operation. Think what that would mean for waiting lists" (17 October, p 1009). I remember my first lesson in the insensitivity of NHS administration in my first house job in Edinburgh 18 years ago. Wide eyed, willing, and on a 1 in 2 rota, I was privileged to work with a dedicated team who decided to have a go at the waiting list.

A fast ex-army locum consultant and an ambitious registrar, long since gone to a chair overseas; led a skilful assault with the support of the anaesthetists, the nurses, the laboratory staff, and the theatre technician. Surgical lists went on late-I rarely left before $9 \mathrm{pm}$ on nights off. Extra lists were fitted in-some on Saturdays. The "local hero" developed an increasingly adventurous minor operations list. As gaps appeared in admission lists patients were telephoned. Discharge summaries were typed immediately by secretarial wizardry. It was exciting and rewarding: the waiting list was halved in six months.

At the end of this time the administration spotted the short waiting list and transferred half of the 15 month waiting list from a ward in the Royal Infirmary along the road. So much for naivety.

A computer screen on the desk would be grand though. In 1984-5 the region asked the paediatric neurology and other wards at Booth Hall Children's Hospital to pilot a clinical costing exercise in collaboration with management consultants Deloitte, Haskins and Sells. ${ }^{12}$ The first attempts were inaccurate but with the participation of the full team the scheme reached a reliable standard. This was reported to the regional officers and a member of the NHS Management Board who visited the hospital. We offered to proceed to a clinical budgeting application with a desk top computer on the ward. But North Manchester Health Authority could not find the resources. Robot, not Godot, will come perhaps, but let's facilitate the administration of our hospital units as well as give computerised waiting list details to referring doctors.

Royal Manchester Children's

IAN MCKINLAY

Royal Mancit,

Manchester M27 1HA

1 Lamb SM, David TJ. Playing with fire: an experiment in clinical budgeting. Br Med f 1985;290:650-1.

2 McKinlay IA. Hospital investigation of a child with epilepsy. In: Ross E, Reynolds E, eds. Paediatric perspectives on epilepsy. Chichester: John Wiley, 1985.

\section{Waiting list statistics}

SIR,-The finding of Dr A Lee, $\mathrm{Mr}$ B Don, and Dr M J Goldacre (7 November, $p$ 1197) that $28 \%$ of patients on the surgical waiting list at any one time are found eventually not to have been admitted for their surgery is mirrored by similar findings at the time when they are offered admission. The first year's statistics compiled by the orthopaedic bed manager at the Leicester General Hospital show that overall $25 \%$ of patients offered admission do not take this up: about half electively cancel their admission and half do not attend, having failed to give any warning. The numbers vary from surgeon to surgeon and week to week, and though the failure rate is higher during the holiday months and at Christmas, there is an appreciable failure all through the year.

Dr Lee and others do not know the fate of those who were not admitted in the Oxford region, and 